\title{
Improving Former Shifted Cultivation Land Using Wetland Cultivation in Kapuas District, Central Kalimantan
}

\author{
WAHYUDI
}

\begin{abstract}
Degraded forest area in Kalimantan could be caused by shifted cultivation activity that be conducted by local peoples in the surrounding forest areas. Efforts to improve the former shifted cultivation area (non productive land) is developing the settled cultivation by use of irrigation system, better paddy seed, land processing, fertilizing, spraying pesticide, weeding, and better acces to the market. Local peoples, especially in Kalimantan, has been depended their food on the shifted cultivation pattern since the long time ago. This tradition could cause forest damage, forest fire, forest degradation, deforestation, and lose out of children education because they were following shifted cultivation activity although itsspace is very far from their home. This research was aimed to improve former shifted cultivation lands using wetland cultivation in order to improve land productivity and to support food securityin the local community. This research was administratively located in Tanjung Rendan Village, Kapuas Hulu Sub-Ddistrict, Kapuas District, Central Kalimantan Province, Indonesia. Data of rice yield from settled cultivation and shifted cultivation were got from 15 households that was taking by random at 2010 to 2011 . Homogeneity test, analysis of variants, and least significant different (LSD) test using SPSS 15.0 for Windows. Result of this research showed that paddy yield at settled cultivation was significantly differentand better than shifted cultivation at 0.05 level. LSD test also indicated that all paddy yields from settled cultivation were significantly different compare to shifted cultivation at the 0.05 level. The community in Tanjung Rendan Villages preferred settled cultivation than shifted cultivation, especially due to higher paddy production. Profit for settled cultivation was IDR10.95 million ha ${ }^{-1}$, meanwhile profit for shifted cultivation was just IDR 2.81 million ha ${ }^{-1}$ only. Settled cultivation pattern could to improve productivity and their prosperity, save natural tropical forest, reducee forest degradation and deforestation on the forest areas.
\end{abstract}

Keywords: degraded forest, paddy, settled cultivation, shifted cultivation

\section{INTRODUCTION}

Large of forest area in Indonesia was 120.35 million ha compare to large of degraded forest land is 21.94 million ha (Ministry of Forestry, 2010). Forest degradation in the form of bushes, underbrush, critical land, and grassland as Imperata cylindrica, is often correlated to the critical land, especially in tropical developing countries (Ministry of Forestry, 2000; Wahyudi, 2009a; Yustika, 2002).

Correspondence: Faculty of Agriculture, Department of Forestry, Palangka Raya University, Indonesia Email:wahyudi888@yahoo.com
There are some cause of forest degradation i.e.illegal logging, illegal occupation of forest land, forest conversion, poorlymanaged forest concession (Ministry of Forestry, 1998; Wahyudi, 2009b), excessive timber demand (Wahyudi, 2011), and population explosion (Singh et al., 1995).

The policy of Ministry of Forestryhas applied the segregate pattern to manage all forest area in Indonesia since 1970s to present (Ministry of Forestry, 1998). This pattern disaggregate between forest area versusthe agricultural area althoughhin reality, there are agriculture activity in the a portion of forest area, such as farm, society garden, plantations, and shifted cultivation (Ministry of Agriculture, 2008; Widianto et al., 2003) They 
oblige to apply forestry commodity only in the forest areas, such as timber estate, reforestation, and forest concession in forest production, whereas in the forest conservation and forest protection must be applied the natural conservation and biodiversity protection respectively (Ministry of Forestry, 1998; Wahyudi, 2011). Thereby, they prohibited other cultivations such as agriculture, horticulture, settlement, animal husbandry etc., in the forest areas, although by defacto, a portion of forest areas had been taken possession by the society for settlement, traditional agriculture (shifted cultivation) since long time (Susilo et al., 2003; Wahyudi, 2011). In the field, this policyactually complicate to development local community in the surrounding forest areas.

The community in the surrounding forest areas havebeen depended on shifted cultivation to get their foods (Susilo et al., 2003), notiwithstanding it contain much problems in order to arrange a better land use, and also it cause continually forest degradation, reducing the environment quality and lose out of children education because their children are following shifted cultivation activity in the site although its space very far from their home (Wahyudi, 2009a). By that very fact in the field, the segregate pattern that be applied by Goverment is really adverse, inclusive of like this case. Carried forward them therewith their farm moving of exit from forest area is impossible (Ministry of Forestry 2007, Wahyudi, 2009a). Integrate pattern policy shall be acceptable along with conducted of construction socialize and improve their agriculture effort although they stay in forest area.

Partner shall pattern be developed so that forestry and agricultural activity earn adjacent life well on the around forest area. One of forms of community construction in the surrounding forest areas is Community Management on Forest Areas (CMoFA) using settled cultivation (Ministry of Forestry, 2010; Wahyudi, 2009a). Way of like this beside able to improve productivity of farm and establish food security also can lessen fast of forest degradation and deforestation. One of CmoFA projects is situated at Tanjung Rendan $\mathrm{V}$ village, Kapuas District, Central Kalimantan Province. Therefore, the research to compare dryland cultivation versus wetland cultivation effectiveness in the degraded land is very important to be conducted.

\section{MATERIALS AND METHODS}

This research was situated at Tanjung Rendan V Village, Kapuas District, Central Kalimantan Province, Indonesia. Among of 120 households in Tanjung Rendan Village, just 15 households who taken a hand in this settled cultivation research because settled cultivation land restrictiveness. The commonest soils found in Kalimantan are inceptisols, moderately weathered soils with a distinct profile.

Cultivation stages for settled cultivation comprised of paddy seed (IR64 and cisadane), land processing (mechanical ploughman), planting, fertilizing (dosis of compost, urea TSP, $\mathrm{KCl}$ were $250 \mathrm{~kg} \mathrm{ha}^{-1}, 150 \mathrm{~kg} \mathrm{ha}^{-1}, 100$ $\mathrm{kg} \mathrm{ha}^{-1}$, and $120 \mathrm{~kg} \mathrm{ha}^{-1}$ respectively), spraying pesticide (answer the purpose), weeding (1 time per 3 weeks), labour cost, and acces to the market, whereas cultivation for shifted cultivation comprised of mount paddy seed (from Agriculture Agency of Kapuas), land processing (burn and slashing), planted with dibble (that is wooden tool with a sharp end for making holes in the ground), fertilizing (using local dosis, casually using compost from burning and slashing and urea of $150 \mathrm{~kg}$ $\mathrm{ha}^{-1}$ ), weeding (answer the purpose, casually of 1 time), labour cost, and acces to the market. Result of paddy (Oriza sativa) from both treatments at 2010and 2011 were determined from 15 households respectively in a random manner were analysed by ANOVA and least significant different (LSD) test by SPSS 19.00.

\section{RESULTS}

Dryland-Shifted Cultivation. Yield of paddy from shifted cultivation system was 1.03 to 1.05 ton/ha (Table 1). On the other case, yield of paddy at shifted cultivation in Kalimantan 
island was 1,3 to 3.6 ton/ha, in Sumatra island was 2.0 to 3.5 ton/ha and in Sulawesi island was 2.3 to 4.4 ton/ha (Noor, 1996). Thereby, yield of paddy from shifted cultivalio in Tanjung Rendan V village was still low.

Table 1. Yield of paddy from settled cultivation and shifted cultivation systems in Tanjung Rendan V village at 2010 and 2011.

\begin{tabular}{|c|c|c|c|c|c|c|c|c|}
\hline \multirow{3}{*}{ No } & \multicolumn{4}{|c|}{ Dryland (Shifted cultivation) } & \multicolumn{4}{|c|}{ Wetland (Settled cultivation) } \\
\hline & \multirow[t]{2}{*}{ Household } & \multicolumn{3}{|c|}{ Yield of paddy (ton/ha) } & \multirow[t]{2}{*}{ Household } & \multicolumn{3}{|c|}{ Yield of paddy (ton/ha) } \\
\hline & & 2010 & 2011 & Average & & 2010 & 2011 & Average \\
\hline 1 & Uhing & 0.71 & 0.91 & 0.81 & Rano & 4.00 & 4.50 & 4.25 \\
\hline 2 & Ancong & 1.01 & 0.98 & 1.00 & Mat Karyani & 5.30 & 5.00 & 5.15 \\
\hline 3 & Buntoro & 1,00 & 1.20 & 1.10 & Prawoto & 4.50 & 4.70 & 4.60 \\
\hline 4 & Cilik Nyarang & 1.20 & 0.89 & 1.05 & Sholihin & 6.00 & 5.70 & 5.85 \\
\hline 5 & Heni & 1.20 & 1.10 & 1.15 & Heni & 4.00 & 4.50 & 4.25 \\
\hline 6 & Tumbak & 0.90 & 0.78 & 0.84 & Juwadi & 5.50 & 5.50 & 5.50 \\
\hline 7 & Ranying & 0.99 & 1.01 & 1.00 & Mela & 5.50 & 5.70 & 5.60 \\
\hline 8 & Elo & 1.02 & 0.90 & 0.96 & Hakim & 3.10 & 4.50 & 3.80 \\
\hline 9 & Anton & 1.30 & 1.20 & 1.25 & Tuhu susilo & 4.20 & 4.10 & 4.15 \\
\hline 10 & Jimad Bangkan & 0.9 & 0.92 & 0.91 & Kandari & 5.10 & 4.50 & 4.80 \\
\hline 11 & Koneng & 0.72 & 1.22 & 0.97 & Doser & 4.00 & 5.10 & 4.55 \\
\hline 12 & Elduring & 1.29 & 1.10 & 1.20 & Udu & 4.00 & 4.50 & 4.25 \\
\hline 13 & Soni & 1.20 & 0.99 & 1.10 & Alfianto & 3.50 & 4.00 & 3.75 \\
\hline 14 & Kunum Ura & 1.00 & 1.32 & 1.16 & Korang & 3.50 & 4.20 & 3.85 \\
\hline \multirow[t]{2}{*}{15} & Heru & 0.99 & 1.20 & 1.10 & Karno Hadi & 4.00 & 5.00 & 4.50 \\
\hline & Average & 1.03 & 1.05 & 1.04 & Average & 4.41 & 4.77 & 4.59 \\
\hline
\end{tabular}
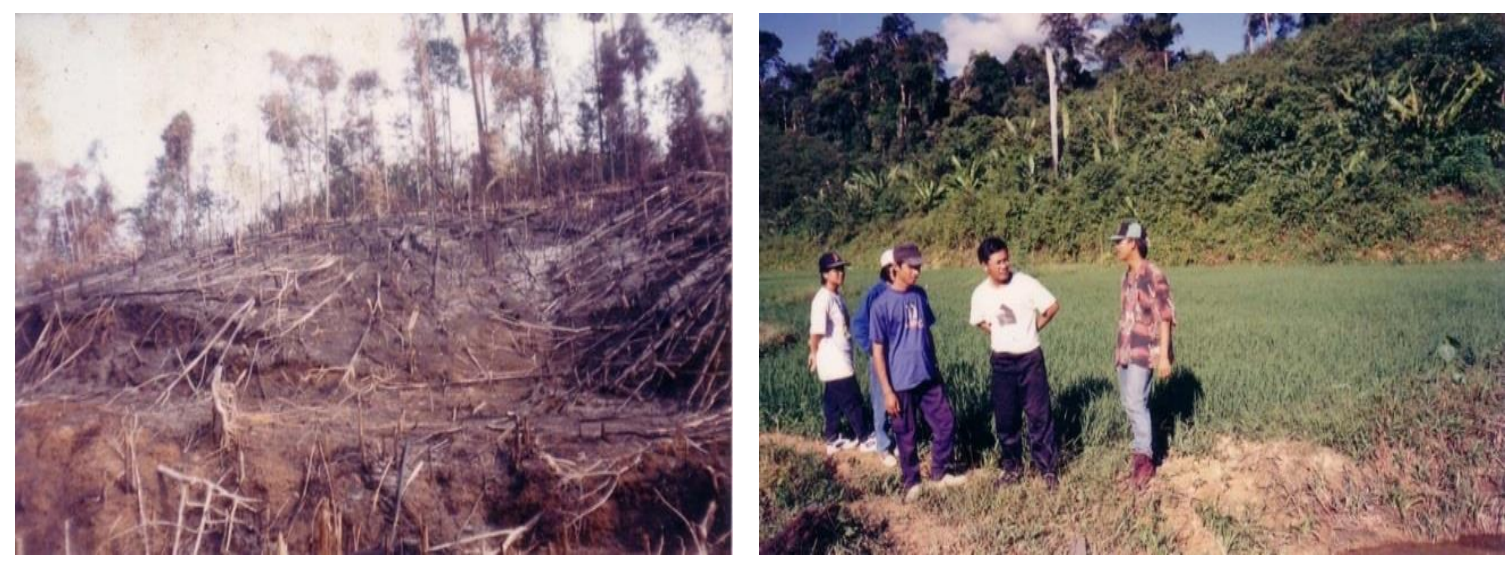

Figure 1. Shifted cultivation (left) and settled cultivation former shifted cultivation areas (right)

Wetland- Ricefield Cultivation. Yield of paddy at wetland or settled cultivation in Tanjung Rendan Village was from 4.41 tonha $^{-1}$ at 2010 to 4.77 tonha $^{-1}$ at 2011 or 4.59 tonha $^{-1}$ in average at 2010 and 2011. Paddy yield from settled cultivation in this site is good enough due to do by society whoo live in forest areas with marginal land conditions. This settled cultivation research was the first cultivation that conducted in Kapuas Hulu Sub District, included in Tanjung Rendan Village. Among 120 households in Tanjung Rendan
Village, just 15 households who taken a hand in this settled cultivation research because settled cultivation land restrictiveness. At first stage, PT Gunung Meranti corp. helped to built some rice fields and irrigation to 15 households.

The highest yield of paddy was obtained by Sholihin of6 tonha ${ }^{-1}$ in 2010 and 5.7 tonha $^{-1}$ in 2011, wwhereas the mean together of 4.59 tonha $^{-1}$. Human factorscould determine the yield of paddy in rice field (Susilo et al., 2003; Wahyudi, 2009a). Workers of eextension 
agent from PT Gunung Meranti company has assisted to motivate and improve result of paddy in the settled cultivation since 2007 (PT.Gunung Meranti, 2011) The ffarmers who coming from Jawa more succeeding in this research because they has experienced to managepaddy in the settled cultivation like as in Jawa, they are Mat Karyani, Sholihin, Mela and Juwadi. Happen to transfer the experience from Jawa peoples to local peoples of Tanjung Rendan Village, and has an effect on goodness at settled cultivation program in here.

Pursuant to analyze of variants, mean yield of paddy at settled cultivation in the year 2010 and 2011 was not significantly differentdue to value of sig.: $0.92>0.05$. Thereby,settled cultivationin Tanjung Rendan Village showed favorable result of paddy yield. In the future, applying the Five Effort of Farmer i.e. the best of seed, irrigation, land management, fertilization and good harvesting were very important to apply in order that to increase agriculture product (Agricultural Research and Development Agency, 2003; 2008; Wahyudi, 2009a).

\section{DISCUSSION}

The mean least yield of paddy had been around Uhing and Tumbak, they were 0.81 tonha $^{-1}$ and 0.84 tonha ${ }^{-1}$ respectively, meanwhile the mean highest yield of paddy had been around Elduring and Anton, they were 1.2 tonha $^{-1}$ and 1.25 tonha $^{-1}$ respectively, whereas the mean yield of paddy was 1.01 tonha $^{-1}$. The mean least yield of paddy was caused by a period of leave temporarily was too short, only 2 to 3 years, hence the farm land fertility not yet returned well (Fisher \& Binkley, 2000; Foresta et al., 2000; Nair, 1993; Susilo et al., 2003). Short leave temporarily could be caused by more and more changing of farm land become people's rubber plantation, other agricultural plantations (Susilo et al., 2003; Widianto et al., 2003) and resident accretion especially from newcomer (Ministry of Forestry, 2007; Singh, 1995; Yustika, 2002). This problem also happened due to traditionally agricultural technique that applied in the field, and general caused by lower farm land fertility in Kalimantan island (Mc Kinnon et al., 2000; Noor, 1996; Widianto et al., 2003).

Traditionally local people in Kalimantan have worked these soils by shifted cultivation, with a short cropping regime and a longer fallow (during 3 to 5 years) to allow fertility to recover (Wahyudi, 2009a). This allows the top soil to regain some humus and organic matter which are important as stores of nutrients and for regulation soil moisture and temperature (Foresta et al., 2000; Wahyudi, 2009a).

Shifted cultivation in Kapuas District has some stages to prepare land and manage paddy, i.e. slashing, burning, and planting of paddy with dibble (that is wooden tool with a sharp end for making holes in the ground) done in mutual assistance (Wahyudi, 2009a). Pursuant to analyze of variants, mean yield of paddy at shifted cultivation in the year 2010 and 2011 was not significantly differentdue to value of sig.: $0.99>0.05$. Thereby,shifted cultivationin Tanjung Rendan Village showed unfavorable result of paddy yield just than the data that informed by Noor (1996).

Settled cultivation and shifted cultivation in this research using organik manure like compost, and inorganic manure like urea, TSP, and KCLto increase of paddy yield. For shifted cultivation just using the local dosis only. Meanwhile, iirrigation to rice filed (settled cultivation) come from accumulating basin and channel that builtby PT Gunung Meranti. Paddy of IR 64 andcisadane were used in this settled cultivation, whereas mountpaddy was used in the shifted cultivation research that gotten from Agriculture Agency of Kapuas District.

Yield of paddy at settled cultivation was better than shifted cultivation. Pursuant to analyze of variant that both patterns were significantly differentdue to value of sig.: $0.00<0.05$. LSD test indicated that all paddy yields from settled cultivation were significantly different and better than all paddy yields from shifted cultivation at the 0.05 level. The community in this research preferred settled cultivation than shifted 
cultivation, especially due to higher paddy production.

The financial analysis indicated that settled cultivation was more benefiting than shifted cultivation, additionally free of some cost to build and maintenance of irrigation and agricultural directive counseling because they were gooten from PT Gunung Meranti. Average paddy yield from settled cultivation was 4.59 ton ha $^{-1}$, this was equally of IDR 20.66 million $\mathrm{ha}^{-1}$, whereas average paddy yield from shifted cultivation was just 1.04 ton $\mathrm{ha}^{-1}$, this was equally of IDR 4.68 million $\mathrm{ha}^{-1}$ only. Cultivation cost for settled cultivation comprised of paddy seed (IR64 and cisadane), land processing (mechanical ploughman), planting, fertilizing (dosis of compost, urea TSP, and $\mathrm{KCl}$ were $250 \mathrm{~kg} \mathrm{ha}^{-1}, 150 \mathrm{~kg} \mathrm{ha}^{-1}$, $100 \mathrm{~kg} \mathrm{ha}^{-1}$, and $120 \mathrm{~kg} \mathrm{ha}^{-1}$ respectively), spraying pesticide (answer the purpose), weeding (1 time per 3 weeks), labour cost, and acces to the market were IDR 9.71 million ha 1 , whereas cultivation cost for shifted cultivation comprised of mount paddy seed (from Agriculture Agency of Kapuas), land processing (burn and slashing), planted with dibble (that is wooden tool with a sharp end for making holes in the ground), fertilizing (using local dosis, casually using compost from burning and slashing and urea of $150 \mathrm{~kg}$ $\mathrm{ha}^{-1}$ ), weeding (answer the purpose, casually of 1 time), labour cost, and acces to the market were IDR 1.872 million ha $^{-1}$. Thereby, profit for settled cultivation was IDR10.95 million $\mathrm{ha}^{-1}$, and profit for shifted cultivation was IDR 2.81 million $\mathrm{ha}^{-1}$.

\section{CONCLUSION}

Traditionally local people in Kalimantan, included local peoples in the Tanjung Rendan Village, have worked these soils by shifted cultivation. This tradition could cause forest damage, forest fire, forest degradation, deforestation and lose out of children education because they were following shifted cultivation activity although itsspace is very far from their home. The peoples in Tanjung Rendan Villages preferred settled cultivation than shifted cultivation, especially due to higher paddy production. Profit for settled cultivation was IDR10.95 million $\mathrm{ha}^{-1}$, meanwhile profit for shifted cultivation was just IDR 2.81 million $\mathrm{ha}^{-1}$ only. Settled cultivation pattern could to improve productivity and their prosperity, save natural tropical forest, reducee forest degradation and deforestation on the forest areas.

\section{ACKNOWLEDGEMENTS}

The author thank for Johannes A. Hoesada, MSc as Director of PT Gunung Meranti. Thanks are also due to Budi Harsono and Mat Karyani to use the plots in rice field (wetland) and access to shifted cultivation area in Tanjung Rendan Village.

\section{REFERENCES}

Agricultural Research and Development Agency, 2003. Guideline of Land Evaluation for Agricultural Commodity. Soil Research Agency, Center for Soil and Agroclimate Research and Development, Bogor.

Fisher R.F., Binkley, 2000. Ecology and Management of Forest Soil. Third Edition. John Wiley \& Sons, Inc., New York.

Foresta H., Kusworo A., Michon G., Djatmiko W.A., 2000. Typical Agroforestry of Indonesia. ICRAF Southeast Asia, Jakarta.

Mckinnon, K., G.Hatta, Hakimah H., Arthur M., 2000. Ecology of Kalimantan. Canadian International Development Agency. Prenhallindo, Jakarta.

Ministry of Agriculture, 2008. Revitalization of Agriculture for Food Security Improvement. Ministry of Agriculture, Republic of Indonesia, Jakarta.

Ministry of Forestry, 1998. Guideline for Indonesia Forestry. Forest-Plantation Research and Development Agency, Ministry of Forestry, Republic of Indonesia, Jakarta.

Ministry of Forestry, 2000. Critical Land Management on Forest Areas. Ministry of Forestry, Republic of Indonesia, Jakarta.

Ministry of Forestry, 2007. Forest Community Development. Background, Fact and Policy. Ministry of Forestry,Republic of Indonesia, Jakarta

Ministry of Forestry, 2010. Intensified Silvicultural System in the Management Unit Models, Concept and Implementation. General Director of Forest Utility,Ministry of Forestry, Republic of Indonesia, Jakarta. 
Nair P.K.R., 1993. An Introduction to Agroforestry. Kluwer Academic Publishers. ICRAF. DordrechtBoston-London.

Noor M., 1996. Paddy in Marginal Land. PT. Penebar Swadaya, Jakarta.

PT.Gunung Meranti, 2011. Revised-The Long Plan of Utilized Forest in PT Gunung Meranti, Periode of 2011-2016. Banjarmasin.

Singh, P., P.S. Pathak, M.M.Roy, 1995. Agroforestry System for Sustainable Land Use. Science Publishers, Inc.

Susilo H.S, Mustofa A.S, Leti S, Tony D, Gustaf A.W, Widianto, 2003. Agroforestry in Indonesia. World Agroforestry Centre (ICRAF), Bogor.

Widianto, Nurheni W., Didik S., 2003. Management and Development of Agroforestry. World Agroforestry Centre (ICRAF), Bogor.

Wahyudi, 2009a. Improving Neglected Land to Support Food Security on the Forest Area. National
Proceeding on Strategy and Handling for Land Resources Crisis to Support Food Security and Energy. Faculty of Agriculture, Departemen of Soil Science and Land Resources, Bogor Agricultural University, Bogor.

Wahyudi, 2009b. Selective cutting and line enrichment planting silvicultural system development on Indonesian tropical rain forest. In: GAFORNInternational Summer School, Georg-August Universität Göttingen and Universität Dresden, Germany.

Wahyudi, 2011. Sustainable Forestry in Central Kalimantan. Education Course of SustainabilityCentral Kalimantan. Hokkaido University and Palangka Raya University.

Yustika A.E., 2002. Critical Land Development. Layout of Indonesia Economics. PT.Gramedia Widiasarana Indonesia, Jakarta. 